\title{
3. From Indianization to Globalization: Tracking Bond in Bollywood
}

\author{
Ajay Gehlawat
}

\begin{abstract}
This chapter uses Bollywood Bond "adaptations" to chart the shifting relationship between India and the West, from the Cold War era to the neoliberal present. It examines how elements of the Bond films were incorporated and "Indianized" in earlier films and how these elements, and the Bollywood film itself, subsequently became more globalized, as can be seen in contemporary Bond adaptations like Farhan Akhtar's Don (2006) and Don 2 (2011). Whereas previously the Bond figure was "Indianized" and elements of the Bond film similarly indigenized via the Bollywood masala formula, what one witnesses in the ensuing transition leading to the contemporary era is how the Bollywood film has become more aligned, both aesthetically and culturally, with contemporary Hollywood film forms.
\end{abstract}

Keywords: Bollywood; masala-Bond; Indianization; globalization

In 1983 James Bond, then played by the aging Roger Moore, arrived in India on what must have been the world's fastest helicopter, passing over the Taj Mahal in Agra in one shot before descending upon Lake Pichola in Udaipur in the next-a distance of some 600 kilometers in mere seconds. Mounting the steps of the ghat, Bond hears the tune of a snake charmer (played by none other than real-life Indian tennis star Vijay Amritraj) which suddenly segues into the Bond theme as he passes by. How is it that an Indian snake charmer knows this tune? Even before Octopussy (UK: John Glen, 1983), the influence of Bond was apparent in popular Hindi films of the 1960 s and 70 . In this chapter, I would like to use the figure of Bond, and the ensuing Bond "adaptations" made in Bollywood, to chart the shifting relationship between India and the West, from the Cold War era to the neoliberal present in which

Verheul, J. (ed.), The Cultural Life ofJames Bond: Specters of oo7. Amsterdam: Amsterdam University Press, 2020 DOI 10.5117/9789462982185_CHO3 
its economic and cultural policies have swung westward, with its films, in turn, increasingly reflecting this transition. This chapter will examine both how elements of the Bond films were incorporated and "Indianized" in earlier films, including Farz (India: Ravikant Nagaich, 1967), Ankhen (India: Ramanand Sagar, 1968), Keemat (India: Ravikant Nagaich, 1973) and Charas (India: Ramanand Sagar, 1976), as well as how these elements, and the Bollywood film itself, subsequently became more globalized following the advent of neoliberalization in the subcontinent, as can be seen in contemporary Bond adaptations such as Farhan Akhtar's Don (India: Farhan Akhtar, 2006) and Don 2 (India: Farhan Akhtar, 2011), as well as related film "updates" of earlier Bond-influenced narratives. Whereas previously the Bond figure was "Indianized" and elements of the Bond film similarly indigenized via the Bollywood masala formula — a culinary term used to describe the mixture of elements on display in the typical Bollywood film - what one witnesses in the ensuing transition leading to the contemporary era is how the Bollywood film itself has become more aligned, both aesthetically and culturally, with the contemporary Hollywood film form.

Tracking Bond in Bollywood via this latter film industry's multiple iterations of this cinematic figure becomes an effective way of charting both the gradual erosion of the masala form, which defined itself through a blending of multiple genres and generic elements, and the particular role that the Bond-influenced narrative has played in effecting such changes. Similarly, just as James Bond films underwent a shift from the comical Roger Moore capers of the 1970 s and early 80 s to the nearly humorless, action-driven features of the twenty-first century starring Daniel Craig, this essay explores how Bollywood has also developed in several corresponding ways. While Indianized Bond characters of the 1970s, for instance, frequently engaged in both song and dance and the typical tongue-in-cheek humor associated with Moore's iterations of this figure, the contemporary Indian version of Bond, as personified by superstar Shah Rukh Khan in the two Don films of Farhan Akhtar, has nearly relinquished his sense of humor even as one sees a corresponding diminution of the earlier quintessential features of the Bollywood film, such as song and dance, in these modern updates. This chapter will closely examine not only the development of such changes but what they specifically entail within and for the "Bollywood ecumene" (Bhaumik 2007, 202), as well as what the resulting aesthetic and cultural shifts, aligned with the figure and figuration of Bond, signify for the contemporary iteration of Bollywood in a transnational era in which its agents, vamps and villains have increasingly come to resemble their western counterparts. 


\section{The Masala-Bond Blend, aka, The Singing and Dancing Agent}

One of the "first A list Bollywood films to capitalize on the James Bond craze" (Stadtman 2015, 205), Ravikant Nagaich's Farz (“Duty," 1967), begins with a very Bondian pre-credits sequence, in which Agent 303 is killed while trying to escape from villains whom he secretly photographed using a miniature camera. The music in this opening sequence is reminiscent of the James Bond theme, even as it is "Indianized" — that is, made to adhere to the Bollywood masala formula, in this case, including a blend of Western and Indian instrumentation. Such Indianization continues after the opening credits, when we are first introduced to our hero, Agent 116, aka Gopal (played by Bollywood star Jeetendra), who is to replace Agent 303. Agent 116 is introduced via a song, immediately following the opening credits and initial scene, in which the station chief tells his underling to find 116, wherever he may be. A cut immediately takes us to a Bollywood song and dance, featuring 116 cavorting and rolling around with a young woman, while wearing tight white pants, white shoes and a red sweater while lip-synching to the song's Hindi lyrics. 116 is repeatedly presented in freeze frames in the beginning of this song sequence as he jumps in the air or, indeed, over his female counterpart while emitting joyous "Ooh-oohs!" After this five minute sequence concludes, the understandably spent couple lie dormant on the ground before Gopal slowly begins whispering words of love in his female companion's ear. Even as he does so, however, he notices someone moving nearby, whose shadowy presence is also signified by ominous mood music on the soundtrack. As the earlier Bond-esque theme reemerges, 116 continues speaking words of love to his female friend while simultaneously creating a ruse to trap the unseen observer, who turns out to be the station chief's underling, Mohan, come to get him for his new mission. In this opening sequence - or, indeed, opening sequences-we thus have a vivid instance of how the Bond narrative is adopted and Indianized via the quintessential element of the popular Hindi film: song and dance. Yet this opening also shows us how these two elements-Bond and Bollywood-coexist somewhat awkwardly, with the film abruptly shifting registers from Bond-spy narrative to Bollywood song and dance. And while Agent 116,

1 This song, Mast Baharon Ka Main Aashiq ("I am the Lover of Blooming Pleasures"), is sung by legendary playback singer Mohammed Rafi. Jeetendra's energetic moves in this song sequence illuminate why he was subsequently given the moniker, "Jumping Jack of Bollywood," even as dancing in white pants and patent-leather shoes became his trademark (Jeetendra Biography; Rajadhyaksha and Willemen 1999, 114). 
like his western counterpart, balances his skills at amour with his equally formidable sleuthing prowess, the manner in which the former expresses his amorous desires is quintessentially aligned with the pathos of the Hindi film in its exuberance and over-the-top nature. ${ }^{2}$ In this way, one sees how the masala-Bond film engages in what Sumita Chakravarty $(1993,4-5)$ labels "imperso-nation," that is, "the play of/on surfaces" which, in turn, "implies a form of subversion," in this case, of the conventional (Western) Bond figure.

One sees a similar confluence of Bondian and Bollywood elements on display in the following year's Ankhen ("Eyes," 1968), in which Dharmendra plays Sunil, the son of an Army chief, who travels the world, visiting Tokyo, Beirut and Cochin in his pursuit of the villains. Sunil's female sidekick, Meenakshi (Mala Sinha), in a nod to the previous year's Bond film You Only Live Twice (UK: Lewis Gilbert, 1967), is a half-Japanese agent whom he first meets in Tokyo, where she is made up to look "Oriental." In the film's first song, set in Japan, Meenakshi switches from one Japanese-themed costume to the next while Sunil wears a beige overcoat and fedora. In a similar vein, and in a slight departure from the previous year's Farz, only Meenakshi sings in this first song sequence, with Dharmendra's Sunil forgoing Jeetendra's enthusiastic lip-synching (and dancing). ${ }^{4}$ Despite this lack of singing and dancing by the Indian agent, the film features several other instances of Indianization, detailed below, along with its several Bondian elements such as sliding partitions, hidden chambers and secret transmitters. A classic instance of such Indianization comes when Agent Sunil arrives in Beirut. While the Bond influence makes its presence felt via the electric guitar-heavy music that plays as he is trailed by villains from the airport, and in his subsequent discovery of an electronic bug (hidden inside a fake poodle) in his hotel room, it is when Sunil goes to a nearby café and places

2 Bond, on the other hand, as personified, e.g., by Sean Connery, tends to be more restrained in his displays of affection, as can be seen in the opening sequence of From Russia with Love (1963), in which it is his female friend who is more (sexually) aggressive and Bond who frequently slaps her exploring hands away. Similarly, for all his physical prowess, Bond never dances, much less in the manner of "Jumping Jack Jeetendra." All of these differences create essentially different forms of masculinity.

3 To some extent the masala-Bond film engages in the type of problematic Orientalism on display in several Bond films though to a lesser degree. For more regarding the Orientalism of Bond films, see Gehlawat (2009).

4 The subsequent shift to Dharmendra for the Bollywood Bond roles of the late 6os and early 70 may indeed reflect the fact that Jeetendra was "more suited to romances and musicals, while Dharmendra more fit the mold of the two-fisted man of action" (Stadtman 2015, 205). Nevertheless, Dharmendra also engaged in song and dance, despite his arguable proclivity for action sequences. 
an order that his cultural distinction (as Indian) becomes apparent. Rather than a shaken martini, Sunil orders chai. Similarly, upon meeting the villain's moll, Princess Zehnab, at a swanky dinner party later that evening, Agent Sunil, dressed in a tuxedo, declines Zehnab's offer of whisky, opting instead for a soft drink. Meanwhile the film's additional song and dance sequences, again primarily featuring Meenakshi and other female dancers, blend Bollywood and Bond elements by frequently using exotic foreign locales as backdrops for their numerous picturizations and, again in a nod to the conventions of popular Hindi cinema, the film ends with a reprise of one of these songs, featuring Sunil and Meenakshi walking hand in hand into the sunset, having defeated the enemy.

Dharmendra reprised his role as the Indian secret agent in Keemat ("Price," 1973), again directed by Nagaich. In this film, Dharmendra takes up the role originally played by Jeetendra, Agent 116, aka Gopal, and the film immediately signifies its adherence to the Bond aesthetic via its overtly cool opening credits sequence which features still images of characters and scenes with western-influenced, guitar-heavy music and breathy voices rhythmically intoning, "Hey! Hero!" Though Nagaich intended Keemat as a sequel to Farz, in the ensuing six years, Stadtman $(2015,205)$ surmises, some of the novelty of such films had most likely worn off, leading Nagaich, perhaps in a compensatory move, to "tak[e] advantage of the era's looser standards with racier content" in his new film. Yet though the film does feature such "racy" content-including the insertion of gratuitous item numbers in the villain's nightclub with women in outlandish and revealing, glittery costumes dancing before the assembled, leering men - most such song sequences still feature a more Indian style of dance choreography, thus articulating such films' cultural distinction from the prototypical Bond narrative which eschews such superfluous elements. ${ }^{5}$ Additional instances of Indianization of the ostensible Bond narrative-increasingly solidified by the "two-fisted" Dharmendra-are also on display throughout the film, particularly with regard to the secret agent's sexual proclivity (or lack thereof). When Gopal enters a woman's room, for instance, while she is showering and she subsequently calls for a towel, it looks like a classic Bond send-up. But then, when the woman realizes Gopal is in the room and shrinks back in embarrassment, the secret agent looks away even as he tosses her a robe and proclaims that he is a sharif ("noble") man and proceeds to lecture her about taking more care when exiting the bath. In a similar vein, when this woman starts removing her clothes in an attempt to seduce the 
secret agent, he asks her what the hurry is and, when she replies, "Business," demurs by noting that he doesn't engage in such "business" with girls. At the same time, when subsequently questioned about his meeting with this woman by another woman, Gopal replies, "When beautiful girls want to meet with me, I don't ask questions." Thus, we see how the Indian secret agent attempts to have it both ways (as does the masala-Bond film, even during this allegedly "looser" era), maintaining a veneer of sexual prowess while, in private, demurring from open sexual invitations.

This uneasy dynamic between Bondian and Indianized elements reaches its apotheosis in Charas ("Hashish," 1976), directed by Ankhen's director, Ramanand Sagar. In this convoluted story, Dharmendra plays Suraj, whose family is apparently killed off by villains in Uganda and who is subsequently recruited by the police as a secret agent to combat drug smugglers (including, as it turns out, those behind the attacks on his own family). As with Keemat, the film features a cool opening credits sequence, with lots of action and hip music, as well as a potpourri of evil villains including some of the era's most notorious, such as Ajit and Amjad Khan, with the former playing the lead villain and the latter, his henchman Robert who, in an "amplification of grotesquery," has an "oatmeal-y facial appliance and a seeming vat of pomade," along with lines, delivered in English, such as, "When I kill them, they stay dead" (Stadtman 2015, 201). At the same time, even as it includes such Bondian villains and Bond-esque trips to foreign locales including Malta, Charas features its fair share of lip-synched song and dance numbers. Similarly, as seen in both Ankhen and Keemat, Dharmendra and his female counterpart, Sudha, played by Hema Malini, display distinctly Indian sensibilities when confronted with stereotypically Western behavior. For instance, in a scene that recalls several others from this era of Hindi film, when Suraj points out a white couple kissing in a bar in Malta to Sudha, she replies, Sharam nahin aati hai? ("Don't they feel ashamed?") and proceeds to defend "Indian virtue" by turning down all of Suraj's subsequent suggestions and sexual innuendos, claiming that such actions only come "after marriage. ${ }^{\prime 6}$ Similarly, instead of a kiss, we get a song and dance sequence featuring Sudha and Suraj, cavorting about in their hotel rooms, singing (or, lip-synching) of their desire for one another but doing nothing more, even though Sudha does engage in a striptease of sorts for Suraj, changing into a sexy black negligee while he watches. Ultimately, however, he is pushed

6 Sharmila Tagore similarly rejects co-star Shammi Kapoor's request for a kiss in An Evening in Paris (1968), also set abroad, claiming that she is "an Indian girl" and that, according to Indian custom, "that... that's only after marriage" (Prasad 1998, 89). 
out of her room and sent back to his, empty-handed. Such moments not only provide vivid instances of the Indianization of the Bond sex scene (imagine Bond lip-synching of his desire but not fulfilling it) but also of the particular role that song and dance has historically played in sublimating such sexual desires. As Rini Bhattacharya Mehta $(2010,11)$ notes, such song sequences "enhanc[e] the suggestive yet minimal physicality of the love scenes' with poetic innuendos, but also ultimately steriliz[e] them; because nothing happens in full-view." Such "carefu[l] circumvent[ion] [of] the issue of sexual contact," in Mehta's (11) view, becomes "the most intriguing idiosyncrasy of Indian popular cinema" and, along with the thematization of the prohibition of public displays of affection (as cultural truth and duty), serve as quintessential markers of the otherwise Bondian film's essentially Indian formulation. As Madhava Prasad (1998, 90-91) notes regarding the Indian context of this era, "[T] he threat posed by a transgression of custom is not only to the family or the institution of marriage but to the nation itself, as if the expansion of the sphere of sexuality threatened to break open the national borders and destroy its identity." It is precisely such "breaking open" of sexual mores and national borders that the twenty-first-century Bollywood-Bond film engages in, as we shall see in the ensuing section, even as such an "opening up" allows for the importation, to some degree, of the cultural politics associated with Bond.

An additional key instance of the Bond narrative being made to fit the Procrustean bed of popular Hindi film conventions, meanwhile, can be seen in Charas's frequent back and forth from song to action to song, as well as in the ensuing ways that such failure to adhere to a more western-oriented linear narrative is almost casually forgiven. After engaging in a song and dance with Sudha upon arriving in Malta, for instance, in which several tourist locations are featured, Suraj arrives at the place where all of the police are waiting to ambush the main villain, casually stating, "Sorry, I got late." "No problem," the white police officer replies just as casually.7 Then, suddenly, in a nod to You Only Live Twice, the lead villain sees the assembled police force and, after leading them on a car chase, escapes when his car is lifted away by a helicopter. Just as suddenly the film cuts to Robert's nightclub, somewhere (else) in Malta, for yet another song and dance, this one featuring Suraj's long-lost sister performing a sexy item number. In such a way, even as one could argue song and dance numbers frequently interrupt the Bondian narrative, one could equally argue that it is the Bond narrative

7 The use of exotic foreign locales, replete with their local denizens, as backdrops for song and dance sequences is a Bollywood staple that continues up to this day. 
which is sandwiched between song and dance numbers, whether featuring the secret agent cavorting with his female lead in a hotel room or before various Maltan tourist locations, or featuring the secret agent's sister dancing in the villain's nightclub. As with the intense action and chase sequences taking place in most Bond films, such song and dances are arguably the most compelling visual attractions of the film. Yet these Bollywood-Bond films of the late 6os and 7os include both types of attractions - song and dance and intense fights and action - thus literally doubling the overall visual pleasure derived from such films. In the ensuing section, we shall see how this quintessential topos of the Bollywood-Bond narrative has (d)evolved, even as the Indian Bond figure has, in turn, grown increasingly globalized in both his outlook and look. While India remained essentially non-aligned during the Cold War era, one still witnesses a rather bellicose nationalism in the films of this era, particularly with regard to its neighbors, especially China, as one sees in the Chairman Mao-like villain of Farz. While the Bollywood-Bond films of the twenty-first century attenuate this earlier era's agonistic framing of Indian and Western cultural elements, they do retain - and to some extent heighten - the nationalism on display in the Cold War-era films. Similarly, even as the interim period-between the 196os/70s and the twenty-first century_-was marked by significant changes in the official Bond franchise, including with regard to both geopolitics (e.g., the end of the Cold War) and cultural dynamics (e.g., regarding gender and race), the Bollywood industry also underwent significant shifts during this period following the liberalization of the Indian economy in the $1990 \mathrm{~s}$ which, in turn, led to marked changes regarding the ensuing make-up of the Bollywood film.

\section{Remaking the Indian Bond}

If there is one actor who has constantly clamored to play James Bond, it is the so-called "King of Bollywood," Shah Rukh Khan (hereafter, SRK). ${ }^{8}$ SRK first had a chance to try out such a role in Farah Khan's directorial debut Main Hoon $\mathrm{Na}$ ("There Is Me, No;" India: Farah Khan, 2004), where he plays an army major who goes undercover at an Indian college to protect a general's daughter from attack by the villains. Khan's entry immediately conjures Bond, as his character, Ram Sharma, "literally drops in like a star from the

8 As, for instance, in an interview in The Scotsman, in which Khan stated, "Man, I want to be James Bond. Please make me the first Indian James Bond” (quoted in Dalton 2002). 
ceiling/sky in explosive sparks" (Gopinath 2017, 8) before "dangl[ing] from wires while killing hostage-takers, shoot[ing] henchmen in slow motion while seemingly flying through the air" (Denison 2010, 191). Even as this film was successful in developing Khan as "an action hero," however, one also witnesses the intrusion of melodrama on "the space of the truncated action performance" (191-92). Just as the film, in other words, "mix[es] the codes of melodrama and action," SRK provides "competing generic codes of performance" (192), engaging, like past Bollywood Bond figures such as Jeetendra and Dharmendra, in both fisticuffs and song and dance. Such a performance becomes a double role of sorts, mixing "action hero" with "romantic hero" (Gopinath 2017, 8) yet these roles remain segmented in a way that differs from the figure of Bond, in whom such elements (action, romance) are typically conflated. As Praseeda Gopinath $(2017,13)$ notes, the trope of the "standard heroic, confident action figure [...] wobbles when it comes to his interactions with the love interest." Even as the film more broadly mirrors this double role by engaging in a form of "genre blending" (185), combining elements of romance, song and dance and action, it also makes (parodic) allusions to contemporary Hollywood action blockbusters like The Matrix (USA: Lana Wachowski and Lilly Wachowski, 1999) and Mission: Impossible (USA: Brian De Palma, 1996) via its use of "Matrix-style 'bullet time"' (Stadtman 2015, 222), which in turn raises the question of whether such "Indian remaking" remains relegated to narrative content or indeed also affects the Bollywood film's "form and coding" (Wright 2015, 137). To come to a better understanding of this complex question and to see how SRK was finally able to play Bond, let us examine his subsequent film, Farhan Akhtar's Don (2006).

Akhtar's Don is itself a remake of an earlier Bollywood film of the same name, directed by Chandra Barot and released in 1978. Even more than Main Hoon $\mathrm{Na}$, this film - in both its original and remade versions - features the use of double role: "that of a dreaded don and that of a street performer who happens to resemble the don and is recruited by the police to penetrate the gang" (Chopra 2007, 220). Yet unlike the original version, which is more akin to the earlier masala-Bond films discussed in the first section of this chapter, the 2006 version of Don is a "Mission: Impossible-style thriller in which Shah Rukh plays an international criminal draped in guns, gadgets, drugs, and blondes" (220). ${ }^{9}$ Along with such quintessentially Bondian elements this remake, released the same year as Daniel Craig's Casino Royale, demonstrates

9 The original version is seen as epitomizing the Bollywood masala style of filmmaking (Dwyer 2005, 88), featuring a combination of song and dance, action sequences and melodrama. 
how the twenty-first-century Bollywood film has grown closer in "form and coding" to its Hollywood counterpart (Wright 2015, 137) even as SRK, like Craig, increasingly "attempts to fit into the 'hard body' masculinity of a new generation of male actors" (Gopinath 2017, 16). However, mirroring its title character's double role, Akhtar's 2006 remake still retains some degree of the original Bollywood masala formula even as it features "a high concentration of Hollywood/foreign film aesthetics" which, in some cases, lead to "abandoning traditional Bollywood conventions altogether" (Wright 2015, 173). Some of these changes - from a more Indianized palette to one more global in its contours-include a shift in settings (while the original Don, played by Amitabh Bachchan, was essentially relegated to Bombay/India, SRK's Don, like his Bondian counterpart, "exhibits an ease in moving between [...] Paris [...] Langkawi [...] Kuala Lumpur, as well as [...] Mumbai” [Seth and Fuchs $2015,71])$ as well as a more "slickly produced" film that adheres to the "song sequence formula" of erstwhile Bollywood yet presents its musical sequences "in the manner of an MTV pop video" (Wright 2015, 174). Similarly, SRK's Don, like his character in Main Hoon Na, still reflects an "imbalance" between his two roles- "cigarette smoking [...] and indestructible" on the one hand (176) and engaging in song and dance on the other-yet offers a fundamentally "harder" form of masculinity overall— "a man with a sense of humor," as SRK notes, "but very cold and very, very mean" ("Making of Don" DVD feature 2006). In a similar vein, the sexuality of the twenty-first-century Bollywood Bond is decidedly grimmer and less inclined towards the frivolity on display in the earlier masala-Bond films such as Farz.

The first song sequence from the film, Yeh Mera Dil ("This, my heart") aptly displays these shifts in form and content, both of which align this remake if not with a particularly Hollywoodian approach then with a "new globalized postmodern cinema aesthetic" (Wright 2015, 179). In the original version of this item song, the erstwhile queen of vamps, Helen, playing the sister of a man whom Don murdered, attempts to trap him via the use of song and dance as a delaying maneuver, distracting him until the police arrive. The updated version of this song, while adhering to the general contours of the original (employing the vamp figure, this time played by Kareena Kapoor, to utilize song and dance as a delaying tactic), features a much more densely layered audio track and techno beat, even as Sunidhi Chauhan's deeper timbre replaces Asha Bhosle's higher pitched voice for the playback. Similarly, the cinematic style of the remade song and dance sequence is rather different from the original and more analogous to an MTV aesthetic, featuring stutter edits that align audio track and image via a series of strobe-effect cuts. In a related vein, while Helen attempts to 
seduce Bachchan's Don in the original, he remains generally impervious or, at best, bemused by her attempts while SRK's Don displays a heightened sexuality, getting it on much more with Kapoor's vamp figure and even getting on top of her in bed near the end of the sequence (while maintaining his "hard" veneer $\left.{ }^{10}\right)$. Additionally, while the original sequence remains confined to the room in which Helen dances, the remake features a crosscut to the police arriving in their high-speed, siren-wailing entourage, even as the music continues playing, thus creating a sound bridge between these two simultaneous events. Such a postmodern cinema aesthetic is also on display in the updated version's other song sequences, which similarly employ MTV-style cinematography, remixed, bass-heavy techno beats, and are more closely interwoven with the surrounding narrative action. Thus, even as the remake of Don retains the quintessential elements of the Bollywood masala form (song and dance), their remixed iterations reflect this film form's increasingly globalized format.

Thanks to a plot twist revealed at the end of the Don remake, ${ }^{11}$ Akhtar brings the titular character back for a second installment five years later. This sequel, unlike either the original or its remake, both of which include five song and dance sequences, includes only one actual song sequence featuring dancing and lip-synching in the entire 153-minute film. This diminution of song and dance, signaling a closer alignment with the Hollywood film form, may also signify the sequel's attempt to be "more appealing internationally" (Ganti 2012, 341). Like the majority of songs in Akhtar's first Don, this sole song sequence hews to an MTV aesthetic, featuring Don's moll and a host of background dancers singing and dancing in a nightclub for the seated, smoking Don (again played by SRK) who, approximately midway through the song, also begins singing and dancing with the others. Other than this four minute sequence, the only other songs in this sequel are a song featured solely on the soundtrack, which plays while Don and his cohorts are seen preparing for a bank heist, and the end credits song sequence, featuring SRK

10 As in the original, Don ultimately kills this vamp figure, once the song ends and her subterfuge is revealed, showing little to no compunction in doing so. While in the original this death is alluded to by the police, in the remake we are actually shown Kapoor's lifeless body lying on the ground while elevator doors continue opening and closing against it. Thus, as with the protagonist's "harder" masculinity, the updated remake is starker in its depictions of violence, which also parallels the increased levels of violence on display in the contemporary Bond films of Craig.

11 Unlike the original Don, who is killed and replaced by his double, the remake reveals that the alleged "softer" double was actually the "harder" Don all along, having killed his double and taken his place. 
and co-star Priyanka Chopra singing and dancing amidst a bevy of CGI and VFX which, in many ways, recalls the opening credits sequences of several contemporary James Bond films. Along with a drastic reduction of the role of song and dance, Don 2 features a much "harder" SRK, whose muscular body is frequently put on display and whose sexuality is decidedly colder. Here, too, one can trace a parallel to Daniel Craig, whose hard and muscular body (and colder sexuality) is similarly put on display in the contemporary Bond films. Such bodies (and sexualities) stand in stark contrast to those of both former Bonds and Bollywood Bonds, including that of Dharmendra who, despite being more in the "two-fisted man of action" mold (Stadtman 2015, 205), rarely presents his (bared) body in such a manner and, in the rare instance when he does, as in an underwater sequence early on in Keemat, reveals a slight paunch. The premise of the Don sequel itself reflects Bollywood's larger aspiration in the twenty-first century as Don, having taken over the Asian (drug) market, now wants to conquer Europe. This westward shift is also signaled in the production crew of the new film, which included a British director of photography and a German action director and was largely shot on location in Germany, where the film premiered at the Berlin International Film Festival. This film, which was an even bigger hit worldwide than Akhtar's earlier Don, is much closer to a typical Bond film in its structuring, featuring a second half sans song and dance that is more concerned with Don's preparations for and implementation of a heist at the Deutsch Zentral Bank. Similarly, the film's convoluted plot hews more to the plot convolutions of a (western) Bond feature than to an erstwhile Bollywood feature, avoiding the type of plot "irrationalities" one still witnesses even in Akhtar's earlier Don remake (e.g., the numerous song and dance sequences).

In thus streamlining the Bollywood narrative, Akhtar creates a new type of Bollywood-Bond with Don 2, one which aptly reflects the changes in Indian cinematic culture, not only since the 1970s but even in the five years since the earlier remake. Along with minimizing or indeed eschewing the role of song and dance, the new film includes "extremely fast and 'realistic' martial arts scenes and stunts" and shifts from a nationalist rhetoric and milieu to one celebrating globalization (Seth and Fuchs 2015, 73-74). Similarly, even as critics have commented on the "darker" nature of Craig's Bond, SRK's Don, like Craig's Bond, "is not vilified;" rather, this anti-hero, like his western counterpart, is "presented as an 'achiever' enjoying a luxurious lifestyle that is only endangered by the multitude of his enemies"12 (74). One can

12 In another interesting parallel, both Craig and SRK serve as brand endorsers for luxury items frequently on display in their films: Omega watches (Craig) and Tag Heuer watches (SRK). The 
thus read the double role of Don as a synecdoche for the larger changes that have taken place in Bollywood and in India. Whereas the original Don features a local Indian (Vijay) who successfully impersonates Don while retaining his quintessentially Indian identity, the local Indian impersonator in Akhtar's remake is unable to survive "exposure to the modern world of globalized crime" (83) and is supplanted by the more global Don who, in turn, paradoxically thrives beneath the camouflaged veneer of an "Indian." Just as this more globalized Don sheds this veneer at the conclusion of Akhtar's first film (en route to taking over Europe), the follow-up makes little claim to any form of Indianness, save for the ostensible Indian nationality of its stars, many of whom more often speak in English, or "Hinglish," than in Hindi.

Such shifts are even more vividly on display in the following year's Agent Vinod (India: Sriram Raghavan, 2012), another "remake" of an earlier 7os era Bollywood-Bond film of the same name. While the director of the remake, Sriram Raghavan, unlike Farhan Akhtar, claimed that his film was not a remake and merely shared the name of the earlier film (IndiaFM 2007), in many ways, as is the case with Don and its remake (and sequel), this film — separated from its "original" by a period of thirty-five years—reflects the same move away from the masala aesthetic of 1970s era Bollywood (with its multiple discordant elements) towards the elimination of these "irrationalities" via the type of Hollywood-inflected sequencing apparent in the later Dons. While the 2012 version is slightly longer than the original 1977 version, it contains only three songs, compared with twice as many in the ' 77 version. Furthermore, while both the songs and the overall aesthetic of the original version are very much in keeping with the 197os Bollywood aesthetic_-including a high degree of spoofing and parabases, dishoom-dishoom fights ${ }^{13}$ and lip-synched song and dance sequences, including one which first introduces us to the title character - the 2012 version, starring Saif Ali Khan as the titular agent, eschews nearly all of these elements, replacing tongue-in-cheek humor and lip-synched songs with grim action sequences and extreme CGI violence. In many ways, one can trace a similar shift in the James Bond films, which went from the comical Roger Moore capers of the late 1970 s and early 80 s to the nearly humorless Daniel Craig action-driven features of the twenty-first century. Additionally, as in the case of Don 2, only one of the film's three song sequences features an actual dance performance and lip-synching; of the

ads for these products in turn frequently reference these films, resulting in symmetrical forms of synergy. For Don 2, Tag Heuer even produced a limited edition Don watch (Seth and Fuchs 2015, 77). 13 Dishoom-dishoom is the colloquial onomatopoeic term for the older Bollywood sound effect accompanying punches. 
remaining two songs, the first is set in a nightclub and interspersed with an action sequence which literally spills over into the song-dance space. The second song sequence in the 2012 Agent Vinod - "Raabta" - even more vividly highlights the growing shift away from the earlier space afforded to the song. In this sequence, while a woman plays a slow, romantic ballad on the piano, the title character shoots a series of villains, interspersed with the sound of silencer-suppressed pistol shots and the ensuing diegetic sounds of people falling over and crashing into various objects. Visually and aurally, this sequence is a far cry from the song sequences of the earlier Agent Vinod which, in keeping with the 7os Bollywood aesthetic, feature the title character lip-synching and cavorting with various women (without shooting them).

The 2012 Agent Vinod also signifies its globalized form in additional ways. Like SRK's Don, the title character, a RAW ${ }^{14}$ agent working for the Indian government, travels all around the world, including Afghanistan, Moscow, St. Petersburg, Morocco, Riga, London and Cape Town and, in keeping with the cosmopolitan nature of the Bond figure, is equally comfortable in all locations (despite frequently being in grave danger). As with Don 2, the pacing of the 2012 Agent Vinod is also more aligned with a western Bond film's itinerary, that is, moving logically from one (global) setting to the next while avoiding the random insertions of song and dance within or between these settings. Instead, as with contemporary Bond films and Don 2, the film is interspersed with intense action sequences though these, too, adhere more to a Hollywood model, forgoing the dishoom-dishoom aesthetics of the earlier Bollywood era. Khan, in playing the title agent, also conforms to the Bondian look, performing intense action and stunts while wearing a black tuxedo and bow tie; indeed, in some ways, one could say his look as the Indian Bond presages that of Craig in his most recent iteration as the secret agent. ${ }^{15}$

At the same time, "regardless of how much [it] may 'steal' from outside sources or stray from [its] own conventions," the 2012 Agent Vinod "cannot be experienced or labeled as [a] foreign, Western or non-Indian production" (Wright 2015, 174). The contemporary Bollywood-Bond remake, in other words, increasingly lacks a fixed cinematic identity, even as the identities of its secret agents have also grown less fixedly Indian, unlike, e.g., the

14 RAW stands for Research and Analysis Wing, the primary foreign intelligence agency of India.

15 One also sees an increased Hollywoodization on display in both the Craig and Bollywood Bond films of the twenty-first century, particularly with regard to the increasing amounts of CGI action sequences in both. In a related vein, even as these two types of Bonds increasingly look the same, the only type of clothing Agent Vinod never dons is Indian garb, thus reflecting the "disavowal of fixed identity" (Chakravarty 1993, 4). 


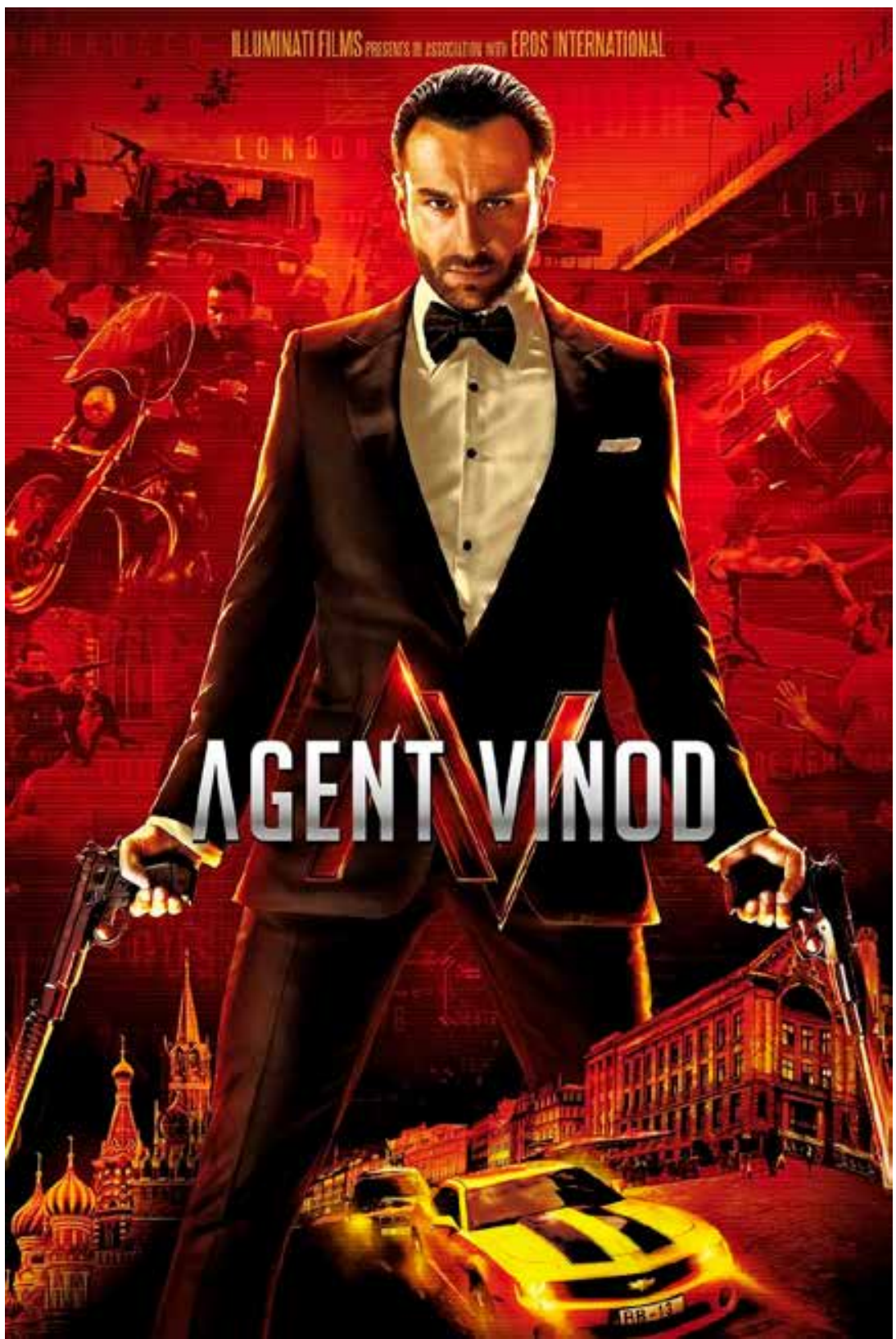

1: Saif Ali Khan as Agent Vinod (2012) in Agent Vinod (India: Sriram Raghavan, 2012). Copyright of Eros International, India. 
chai-drinking agent of Ankhen. A classic instance of this can be seen in the film's ending(s). The film first concludes with Agent Vinod, having completed his missions and newly shaven, approaching a white woman in a bikini on a Cape Town beach. As the woman flirtatiously asks him what his name is, Agent Vinod removes his sunglasses and smiles at her as the screen goes black. However this "Bondian" ending is immediately followed by a more "Bollywood" one, featuring an end credits song sequence, in which Khan goofily dances and playacts before a surveillance camera, while a woman, watching from the surveillance booth, grows increasingly turned on by his moves and joins him in an embrace as the two walk towards the camera together in slow motion. In such a way, the 2012 Agent Vinod pledges its (nominal) allegiance to both Hollywood and Bollywood ecumenes, providing endings that correspond to both film forms and, in the process, producing "a hybrid cinematic style that deviates from both Western and traditional Indian modes of filmmaking"16 (Wright 2015, 174).

\section{Conclusion: A Gentleman's Bond Fatigue?}

Even as the Bollywood film form has grown increasingly streamlined via its contemporary Bondian iterations, the James Bond films of Daniel Craig have increased in their overall length, with three of the last four Bond features clocking in at over 140 minutes. Such a temporal correspondence may belie the inner shifts underlying the internal dynamics of either film form yet it does point to shared tendencies, both in form and content, which are increasingly on display. Yet even as Bollywood has apparently embraced the harder, contemporary Bond aesthetic, a recent film seems to suggest at least a passing fatigue with the franchise. ${ }^{17} \mathrm{~A}$ Gentleman (India: Krishna D.K. and Raj Nidimoru, 2017) begins with Gaurav (Sidharth Malhotra), a nice but boring guy who resides in Miami and drives his minivan to and from work at precisely the speed limit. In a parallel narrative the film presents Rishi (also played by Malhotra), an Indian secret agent who sports tuxedos and a light beard and works for "Unit X," traveling to Bangkok to steal documents from the Chinese embassy and engaging in high speed chases and shootouts. At first glance, then, this appears to be yet another instance of the double role, with nice guy Gaurav and secret agent Rishi to switch identities. Yet when Rishi's motorcycle crashes after his opening 
mission, he sits on the ground in his disheveled tux, pulls out a cigarette and proclaims, "My life sucks." While Craig, too, has shown Bond-fatigue in his recent films, he invariably returns to the game, grimmer and more determined to "finish the job" each time. Rishi, meanwhile, decides to walk away from his life as a secret agent and, in an interesting twist, the film reveals that Rishi is actually Gaurav, having left his line of work to pursue his suburban dream. Needless to say, his former life pursues him and Gaurav soon finds himself reprising his alter identity in an attempt to thwart his former colleagues who have come to either reenlist or retire him. "There was a time you were like Bond," one of his former colleagues says, upon meeting the erstwhile secret agent in his suburban Florida home. "Now look how domesticated you've become." Bollywood has also engaged in such domestication (of Bond narratives) over the past half-century yet, like Gaurav, contemporary Bollywood is increasingly showing signs of repudiating its former identity, in favor of a more Hollywoodesque façade. However, just as Gaurav finds it hard to walk away from his life as a secret agent, contemporary Bollywood films like $A$ Gentleman demonstrate that, while it may be possible to transplant the Indian agent from his home country to the West, he ultimately remains a secret agent, that is, one who will always return. Even as the film concludes with Gaurav (or is it Rishi?) blowing up his suburban home and speeding away in a yellow convertible with his girlfriend, Bollywood returns via the end credits song sequence, featuring Gaurav and his girlfriend lip-synching and dancing to a song that has little, if anything, to do with the plot.

\section{Works Cited}

Bhaumik, Kaushik. 2007. "Lost in Translation: A Few Vagaries of the Alphabet Game Played Between Bombay Cinema and Hollywood." In World Cinema's 'Dialogues' with Hollywood, edited by Paul Cooke, 201-17. New York: Palgrave Macmillan.

Chakravarty, Sumita. 1993. National Identity in Indian Popular Cinema, 1947-1987. Austin: University of Texas Press.

Chopra, Anupama. 2007. King of Bollywood: Shah Rukh Khan and the Seductive World of Indian Cinema. New York: Warner Books.

Dalton, S. 2002. "Meet the Khan-Do Guy." The Scotsman, August 14, 2002, 5.

Denison, Rayna. 2010. "Bollywood Blends: Genre and Performance in Shahrukh Khan's Post Millennial Films." In Genre and Performance: Film and Television, edited by Christine Cornea, 184-204. Manchester: Manchester University Press.

Dwyer, Rachel. 2005. 100 Bollywood Films. London: British Film Institute. 
Ganti, Tejaswini. 2012. "No Longer a Frivolous Singing and Dancing Nation of Movie-Makers: The Hindi Film Industry and Its Quest for Global Distinction.” Visual Anthropology 25: 340-65.

Gehlawat, Ajay. 2009. "Kamasutra Bond-ing." In The James Bond Phenomenon: A Critical Reader, Second Edition, edited by Christoph Lindner, 268-84. Manchester: Manchester University Press.

Gehlawat, Ajay. 2017. "The Picture Is Not Yet Over!: The End Credits Song Sequence in Bollywood." South Asian Popular Culture 15, no. 2-3: 203-16.

Gopinath, Praseeda. 2017. "A Feeling You Cannot Resist': Shah Rukh Khan, Affect, and the Re-Scripting of Male Stardom in Hindi Cinema." Celebrity Studies 9, no. 1: 1-19.

IndiaFM News Bureau. 2007. "Agent Vinod is not a Remake of Rajshri Film." Bollywood Hungama, October 12, 2007, www.bollywoodhungama.com/movies/ features/type/view/id/3212.

Jeetendra Biography. n.d. Lifestyle Lounge. Accessed December 1, 2017, http:// lifestyle.iloveindia.com/lounge/jeetendra2935.html.

Mehta, Rini Bhattacharya. 2010. "Bollywood, Nation, Globalization: An Incomplete Introduction." In Bollywood and Globalization: Indian Popular Cinema, Nation, and Diaspora, edited by Mehta and Rajeshwari V. Pandharipande, 1-14. London: Anthem.

Prasad, M. Madhava. 1998. Ideology of the Hindi Film: A Historical Construction. New Delhi: Oxford University Press.

Rajadhyaksha, Ashish, and Paul Willemen. 1999. Encyclopaedia of Indian Cinema, Revised Edition. London: British Film Institute.

Seth, Aradhana, and Bernhard Fuchs. 2015. "The Don's World: Designing the Milieu of Shah Rukh Khan.” In SRK and Global Bollywood, edited by Rajinder Dudrah, Elke Mader, and Fuchs, 70-97. New Delhi: Oxford University Press.

Stadtman, Todd. 2015. Funky Bollywood: The Wild World of 1970 Indian Action Cinema: A Selective Guide. Godalming, Surrey: FAB Press.

Wright, Neelam Sidhar. 2015. Bollywood and Postmodernism: Popular Indian Cinema in the $27^{\text {st }}$ century. Edinburgh: Edinburgh University Press.

\section{Selected Filmography}

Agent Vinod. Dir. Deepak Bahry. India: Sargam Pictures, 1977.

Agent Vinod. Dir. Sriram Raghavan. India: Dreamaker Productions, 2012.

A Gentleman. Dir. Krishna D.K. and Raj Nidimoru. India: Fox Star Studios, 2017.

Ankhen. Dir. Ramanand Sagar. India: Sagar Art International, 1968.

Charas. Dir. Ramanand Sagar. India: Sagar Art International, 1976.

Don. Dir. Chandra Barot. India: DEI, 1978. 
Don. Dir. Farhan Akhtar. India: Excel Entertainment, 2006.

Don 2. Dir. Farhan Akhtar. India: Excel Entertainment, 2011.

Farz. Dir. Ravikant Nagaich. India: Vijayalakshmi Pictures, 1967.

Keemat. Dir. Ravikant Nagaich. India: Bharati International Films, 1973.

Main Hoon Na. Dir. Farah Khan. India: Eros International, 2004.

\section{About the Author}

Ajay Gehlawat is Professor of Theatre and Film at Sonoma State University. He is the author of Reframing Bollywood: Theories of Popular Hindi Cinema (2010) and Twenty-First Century Bollywood (2015), as well as editor of The Slumdog Phenomenon: A Critical Anthology (2013). Most recently, he co-edited The Evolution of Song and Dance in Hindi Cinema (2019), a special issue of the journal of South Asian Popular Culture. His previous work on Bond and Bollywood appears in the second edition of The James Bond Phenomenon: A Critical Reader (2009). 
